\title{
MOLECULAR IDENTIFICATION OF Candida dubliniensis ISOLATED FROM ORAL LESIONS OF HIV-POSITIVE AND HIV-NEGATIVE PATIENTS IN SÃO PAULO, BRAZIL
}

\author{
Jorge Kleber CHAVASCO(1), Claudete Rodrigues PAUlA(2), Mario Hiroyuki HIRATA(3), Natanael Atilas ALEVA(4), Carlos Eduardo de MELO(5), \\ Walderez GAMBALE(2), Luciana da Silva RUIZ(2) \& Marília Caixeta FRANCO(6)
}

\begin{abstract}
SUMMARY
Candida dubliniensis is a new, recently described species of yeast. This emerging oral pathogen shares many phenotypic and biochemical characteristics with $C$. albicans, making it hard to differentiate between them, although they are genotypically distinct. In this study, PCR (Polymerase Chain Reaction) was used to investigate the presence of $C$. dubliniensis in samples in a culture collection, which had been isolated from HIV-positive and HIV-negative patients with oral erythematous candidiasis. From a total of 37 samples previously identified as $C$. albicans by the classical method, two samples of $C$. dubliniensis (5.4\%) were found through the use of PCR. This study underscores the presence of $C$. dubliniensis, whose geographical and epidemiological distribution should be more fully investigated.
\end{abstract}

KEYWORDS: HIV-positive; HIV-negative; Candida dubliniensis; PCR.

\section{INTRODUCTION}

An increased incidence of fungal infections has been well documented throughout the last decade. The most important factor contributing to this phenomenon has been the increased number of immunocompromised individuals. As a result, many species previously unassociated with human diseases have become important pathogens, some examples being Penicillium marneffei, Emmonsia pasteurina and Candida dubliniensis ${ }^{6,30}$.

Candida dubliniensis was first identified as a new species in 1995 in Dublin, Ireland ${ }^{39}$. Since then, infections by this yeast have been widely reported in a large number of HIV-positive and AIDS patients ${ }^{23}$, being isolated mainly from the oral cavity ${ }^{9}$. Moreover, $C$. dubliniensis has been implicated as a causative agent for oral candidoses and HIVnegative individuals, both in healthy individuals and diabetics ${ }^{42,43}$.

This species shares many phenotypic and biochemical characteristics with $C$. albicans ${ }^{39}$, making it difficult to differentiate between the two species, since $C$. dubliniensis expresses the serotype A of $C$. albicans, and is able to form germ tubes and abundant numbers of chlamydoconidia ${ }^{3,4,39,41}$. Moreover, $C$. dubliniensis is characterized by a high resistance to fluconazole, and the susceptible isolates are able to develop resistance to this drug in vitro ${ }^{26,40}$. This high degree of similarity between the two species has contributed to the identification of some isolates of $C$. dubliniensis as $C$. albicans ${ }^{31}$. This species has most likely been present in the community for long time, although identified as C. albicans $^{36}$.

Therefore, various phenotypic methods for the identification of $C$. dubliniensis and its differentiation from $C$. albicans have been reported. These tests include: the formation of chlamydospores ${ }^{39}$; the pattern of carbohydrate assimilation $^{33}, \beta$-D-glucosidase activity ${ }^{35}$; the color of colonies after seeding in different mediums such as CHROMagar Candida, Staib agar ${ }^{37}$, Niger agar ${ }^{17}$, Tobacco agar ${ }^{13}$ and others; as well as growth in Sabouraud agar at temperatures between 42 and $45^{\circ} \mathrm{C}^{31}$.

However, individual variations among the strains have been reported for these phenotypic characteristics ${ }^{3,39}$, raising the necessity to study its genotypic characteristics. Analyses of the DNA of different samples of $C$. dubliniensis have demonstrated that this species presents conserved sequences of DNA elements, these being important in the identification of isolates for a differential diagnosis of candidiasis between $C$. dubliniensis and C. albicans ${ }^{11}$.

Currently, there exists a wide variety of molecular techniques able to identify $C$. dubliniensis, which include: DNA tests using analyses with restriction endonucleases, methods based in pulsed field electrophoresis, DNA tests using probes, as well as PCR-based methods ${ }^{16,19,28,42}$.

The definitive identification of $C$. dubliniensis is still a problem in

(1) Universidade Federal de Alfenas, UNIFAL, UNIFENAS and UNINCOR (postdoctorate ICB/USP), MG, Brazil

(2) Departamento de Microbiologia do Instituto de Ciências Biomédicas da Universidade de São Paulo, SP, Brazil.

(3) Departamento de Análises Clínicas da Universidade de São Paulo, SP, Brazil

(4) UNINCOR, Três Corações, MG, Brazil.

(5) Departamento de Análises Clínicas da Universidade de São Paulo, SP, Brazil

(6) Universidade Federal de Alfenas, UNIFAL, Alfenas, MG, Brazil.

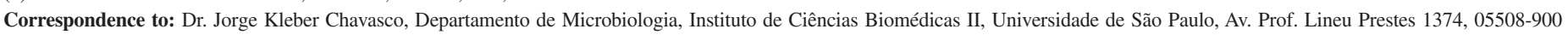
São Paulo, SP, Brazil. Tel: 55.11.3091-7294; Fax: 55.11.3091-7354; e-mail: jkchavasco@uol.com.br 


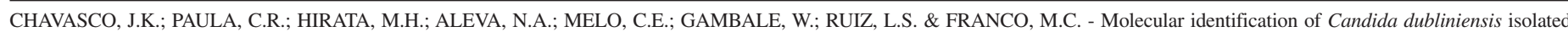
from oral lesions of HIV-positive and HIV-negative patients in São Paulo, Brazil. Rev. Inst. Med. trop. S. Paulo, 48(1): 21-26, 2006.

routine laboratories; it is therefore necessary to know the phenotypic and genotypic characteristics of the isolates to obtain a final characterization. Studies on the incidence of this yeast, carried out by reference laboratories, are necessary for a better understanding of the epidemiology of this new species, especially in South America, where its frequency is not well known ${ }^{5}$.

In this study, PCR (polymerase chain reaction) was used to identify the presence of $C$. dubliniensis in samples isolated from HIV-positive and HIV-negative patients with oral erythematous candidiasis, in the city of São Paulo, Brazil.

\section{MATERIAL AND METHODS}

Yeast isolates: This study involved 39 isolates of yeasts from HIVpositive and HIV-negative patients with erythematous oral candidiasis, which had originally been identified by the classical method ${ }^{15}$. All the patients released the HIV tests by the ELISA method. These samples were kept, for nine months, at the culture collection of the Laboratory of Pathogenic Yeasts, Department of Microbiology, Biomedical Science Institute, University of São Paulo (ICB II/USP). Parallel to this, analyses were made of standard samples of $C$. albicans (LSHT 330) and $C$. dubliniensis (ATCC 777).

DNA analysis: The DNA analyses were carried out on the isolated samples using PCR, according to MAGEE et al. ${ }^{18}$, PFALLER et al. ${ }^{29}$ and SMITH et al. ${ }^{38}$.

DNA extraction: Each sample was inoculated into $5 \mathrm{~mL}$ of YPD medium and incubated for 18 hours at $37{ }^{\circ} \mathrm{C}$. After incubation, $1.5 \mathrm{~mL}$ of the culture was transferred to an Eppendorf tube and centrifuged at $10,000 \mathrm{rpm}$ for five minutes, under refrigeration. The supernatant was discarded, the pellet was resuspended by vortexing after addition of 1 $\mathrm{mL}$ sorbitol (Merck), and the resulting suspension was centrifuged at $10,000 \mathrm{rpm}$ for two minutes. The pellet was resuspended in $1 \mathrm{~mL}$ of lyticase buffer $(50,000 \mathrm{U}$ - Sigma) with $350 \mu \mathrm{g} / \mathrm{mL}$ of that enzyme. The Eppendorf tube was then incubated at $30{ }^{\circ} \mathrm{C}$ in a humidified incubator for 30 minutes and subsequently centrifuged at $10,000 \mathrm{rpm}$ for one minute. The supernatant was discarded and $0.5 \mathrm{~mL}$ of the digestion solution was added to the tube containing the pellet. The tube was then incubated at $70{ }^{\circ} \mathrm{C}$ for 30 minutes in a humidified incubator. The Eppendorf tube was then left at room temperature for 10 minutes, followed by the addition of $50 \mu \mathrm{L}$ of $5 \mathrm{M}$ potassium acetate solution. After 60 minutes at $0{ }^{\circ} \mathrm{C}$, the Eppendorf tube was centrifuged at $10,000 \mathrm{rpm}$ for 15 minutes. The supernatant was transferred to another Eppendorf tube containing $1 \mathrm{~mL}$ of $95 \%$ ethanol (Merck) for the precipitation of DNA. Then the tube was centrifuged at $10,000 \mathrm{rpm}$ for five minutes and the sediment was washed twice with $0.5 \mathrm{~mL}$ of $70 \%$ ethanol (Merck). The precipitated and washed DNA was centrifuged at 10,000 rpm for five minutes. Then, the sediment was resuspended in $100 \mu \mathrm{L}$ of TE (Tris + EDTA).

Estimation of the quantity of DNA: The agarose gel (Sigma) was prepared at $1 \%$ in TBE buffer and placed on an acrylic plate for an 8 -toothed comb, and covered by TBE run buffer on a horizontal electrophoresis plate. Each well was loaded with $10 \mu \mathrm{L}$ of a mixture of the extracted DNA with bromophenol blue stain $(\mathrm{V} / \mathrm{V})$. The run was carried out at $90 \mathrm{~V}$ for 30 minutes, until the material reached the opposite end of the gel. The gel was stained with ethidium bromide in a concentration of $1 \mu \mathrm{L}$ of a $20 \mathrm{mg} / \mathrm{mL}$ stock solution in $100 \mu \mathrm{L}$ of distilled water, for 15 minutes. The total-DNA band was observed in a UV transilluminator.

PCR reaction: According to MANNARELLI \& KURTZMAN, $1998^{19}$. The primers were obtained from Life Technologies do Brasil. Two pairs of the primers were used: one for $C$. dubliniensis (sense: CDU2 - 5'AGT TAC TCT TTC GGG GGT GGC CT 3'; anti-sense: NL4CAL - 5' AAG ATC ATT ATG CCA ACA TCC TAG GTA AA 3') and another for $C$. albicans (sense: CAL5 - 5' TGT TGC TCT CTC GGG GGC GGC CG 3'; anti-sense: NL4CAL - 5' AAG ATC ATT ATG CCA ACA TCC TAG GTA AA 3'). The mix was prepared in an Eppendorf tube with $10 \mathrm{x} \mathrm{MgCl}_{2}(2 \mathrm{mM}), 0.2 \mathrm{mM}$ of dNTP, $0.4 \mu \mathrm{M}$ of each primer, $1 \mathrm{U}$ of Taq and $2 \mu \mathrm{L}$ of the sample, resulting in a final volume of $50.0 \mu \mathrm{L}$. Amplification was carried out in a PTC-200 thermal cycler (Peltier Thermal Cycler, MJ Research) as follows: $98{ }^{\circ} \mathrm{C}$ for three minutes, $95{ }^{\circ} \mathrm{C}$ for one minute, $52{ }^{\circ} \mathrm{C}$ for 1.5 minutes, $72{ }^{\circ} \mathrm{C}$ for 10 minutes, for total of 35 cycles. After the DNA of the sample was amplified, it was submitted to electrophoresis on a horizontal plate (Horizon 58-Life Technologies) in 1\% agarose gel in TBE buffer at $100 \mathrm{~V}$ for 35 minutes. The gel was then stained with ethidium bromide (Sigma) and the DNA bands were observed in a UV transilluminator fitted with a video camera linked to a computer (Multiimage Light Cabinet by Alpha Innotech Corporation) and photographed.

\section{RESULTS}

The results obtained in the amplification of the fragments using the primers CAL5 and NL4CAL (C. albicans), and CDU2 and NL4CAL (C. dubliniensis) are shown in Table 1 .

The samples numbered from 3 to 24 are from HIV-negative patients, and those numbered from 25 to 39 are from HIV-positive patients. The samples numbered $3,4,5,6,7,8,9,10,11,12,13,14,15,16,17,18$, $19,21,22,23,24,25,26,27,28,29,30,32,33,34,35,36,37,38$ and 39 produced fragments with the primers CAL5 and NL4CAL and were identified as $C$. albicans. In relation to the primers CDU2 and NL4CAL, only the samples $20(25 \mathrm{P})$ and $31(15 \mathrm{H})$ produced fragments, being therefore identified as C. dubliniensis (Fig. 1).

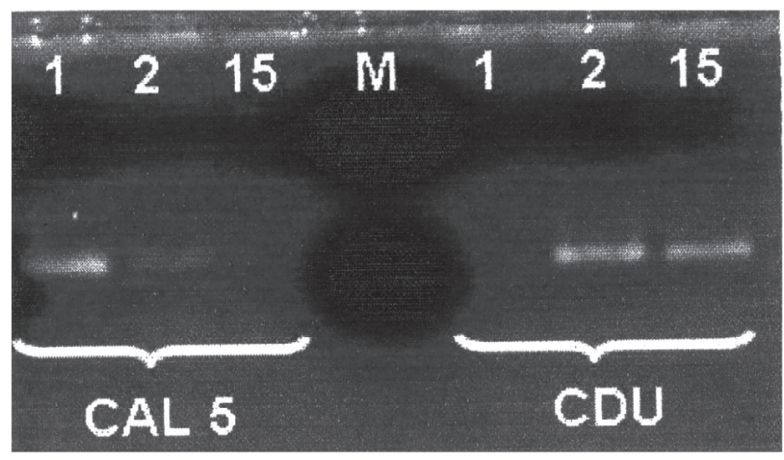

$* 15 \mathrm{H}=$ corresponds to ICB31

Fig. 1 - Electrophoretic analysis of the products obtained through the amplification of the genomic DNA of isolate $15 \mathrm{H}$ and of the standards for Candida albicans (1) and Candida dubliniensis (2) using the primers CAL5 and NL4CAL, and CDU2 and NL4CAL. 


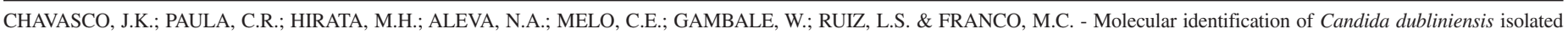
from oral lesions of HIV-positive and HIV-negative patients in São Paulo, Brazil. Rev. Inst. Med. trop. S. Paulo, 48(1): 21-26, 2006.

Table 1

Results for the samples of yeast used in the PCR reaction with the primers CAL5 and NL4CAL (C. albicans), and CDU2 and NL4CAL (C. dubliniensis)

\begin{tabular}{|c|c|c|c|c|c|}
\hline \multirow{2}{*}{$\begin{array}{l}\text { ICB/USP } \\
\text { reference } \\
\text { number }\end{array}$} & \multirow[t]{2}{*}{ Sample } & \multicolumn{2}{|c|}{$\begin{array}{l}\text { Results of the amplification } \\
\text { of the fragments }\end{array}$} & \multirow[t]{2}{*}{$\begin{array}{l}\text { Identification by } \\
\text { the classical method** }\end{array}$} & \multirow[t]{2}{*}{$\begin{array}{c}\text { Identification } \\
\text { using PCR }\end{array}$} \\
\hline & & $\begin{array}{c}\text { Primers CAL5 } \\
\text { and } N L A C A L\end{array}$ & $\begin{array}{l}\text { Primers } C D U 2 \\
\text { and } N L A C A L\end{array}$ & & \\
\hline $01 *$ & LSHT 330 & + & - & C. albicans & C. albicans \\
\hline $02 *$ & ATCC 777 & - & + & C. dubliniensis & C. dubliniensis \\
\hline 03 & $28 \mathrm{P}$ & + & - & C. albicans & C. albicans \\
\hline 04 & $13 \mathrm{P}$ & + & - & C. albicans & C. albicans \\
\hline 05 & $20 \mathrm{P}$ & + & - & C. albicans & C. albicans \\
\hline 06 & $08 \mathrm{P}$ & + & - & C. albicans & C. albicans \\
\hline 07 & $18 \mathrm{P}$ & + & - & C. albicans & C. albicans \\
\hline 08 & $04 \mathrm{P}$ & + & - & C. albicans & C. albicans \\
\hline 09 & $35 \mathrm{P}$ & + & - & C. albicans & C. albicans \\
\hline 10 & $02 \mathrm{P}$ & + & - & C. albicans & C. albicans \\
\hline 11 & $23 \mathrm{P}$ & + & - & C. albicans & C. albicans \\
\hline 12 & $22 \mathrm{P}$ & + & - & C. albicans & C. albicans \\
\hline 13 & $06 \mathrm{P}$ & + & - & C. albicans & C. albicans \\
\hline 14 & $17 \mathrm{P}$ & + & - & C. albicans & C. albicans \\
\hline 15 & $37 \mathrm{P}$ & + & - & C. albicans & C. albicans \\
\hline 16 & $27 \mathrm{P}$ & + & - & C. albicans & C. albicans \\
\hline 17 & $34 \mathrm{P}$ & + & - & C. albicans & C. albicans \\
\hline 18 & $24 \mathrm{P}$ & + & - & C. albicans & C. albicans \\
\hline 19 & $39 \mathrm{P}$ & + & - & C. albicans & C. albicans \\
\hline 20 & $25 \mathrm{P}$ & - & + & C. albicans & C. dubliniensis \\
\hline 21 & $32 \mathrm{P}$ & + & - & C. albicans & C. albicans \\
\hline 22 & $44 \mathrm{P}$ & + & - & C. albicans & C. albicans \\
\hline 23 & $11 \mathrm{P}$ & + & - & C. albicans & C. albicans \\
\hline 24 & $40 \mathrm{P}$ & + & - & C. albicans & C. albicans \\
\hline 25 & $07 \mathrm{H}$ & + & - & C. albicans & C. albicans \\
\hline 26 & $06 \mathrm{H}$ & + & - & C. albicans & C. albicans \\
\hline 27 & $23 \mathrm{PH}$ & + & - & C. albicans & C. albicans \\
\hline 28 & $17 \mathrm{H}$ & + & - & C. albicans & C. albicans \\
\hline 29 & $23 \mathrm{LH}$ & + & - & C. albicans & C. albicans \\
\hline 30 & $26 \mathrm{H}$ & + & - & C. albicans & C. albicans \\
\hline 31 & $15 \mathrm{H}$ & - & + & C. albicans & C. dubliniensis \\
\hline 32 & $01 \mathrm{H}$ & + & - & C. albicans & C. albicans \\
\hline 33 & $14 \mathrm{H}$ & + & - & C. albicans & C. albicans \\
\hline 34 & $09 \mathrm{H}$ & + & - & C. albicans & C. albicans \\
\hline 35 & $13 \mathrm{H}$ & + & - & C. albicans & C. albicans \\
\hline 36 & $03 \mathrm{H}$ & + & - & C. albicans & C. albicans \\
\hline 37 & $21 \mathrm{PH}$ & + & - & C. albicans & C. albicans \\
\hline 38 & $25 \mathrm{H}$ & + & - & C. albicans & C. albicans \\
\hline 39 & $11 \mathrm{H}$ & + & - & C. albicans & C. albicans \\
\hline
\end{tabular}

*Samples 1 and 2 = standards for C. albicans and C. dubliniensis; ** Kurtzman \& Fell ${ }^{15}$. 


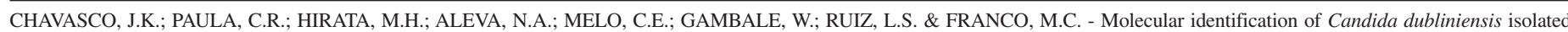
from oral lesions of HIV-positive and HIV-negative patients in São Paulo, Brazil. Rev. Inst. Med. trop. S. Paulo, 48(1): 21-26, 2006.

The size of the fragment amplified by primers CAL5 and NL4CAL, and by primers CDU2 and NA4CAL, being $175 \mathrm{bp}$, corresponds to those observed by MANNARELLI \& KURTZMAN (1998), thus allowing for the identification of the two respective species.

\section{DISCUSSION}

C. dubliniensis is a yeast species recently described as an opportunistic pathogen associated with oral candidiasis, particularly in HIV-positive individuals and AIDS patients ${ }^{41}$.

This species is phenotypically similar to C. albicans, which has resulted in problems in the identification of clinical samples ${ }^{8}$, as well as in the reidentification of isolates kept in culture collections and initially identified as C. albicans.

In a retrospective study carried out on a collection of yeast, COLEMAN et al. ${ }^{3}$ demonstrated that $2 \%$ of the isolates originally identified as $C$. albicans were actually $C$. dubliniensis. ODDS et al. ${ }^{27}$ reidentified 2589 cultures in a culture collection initially identified as C. albicans, finding that $2.1 \%$ were actually $C$. dubliniensis. JABRARIZK et al. ${ }^{10}$ found that $1.2 \%$ of 1251 isolates originally identified as C. albicans were actually C. dubliniensis. COLOMBO et al. ${ }^{5}$ investigated the presence of $C$. dubliniensis among 548 isolates kept in a collection and previously identified as C. albicans, finding that 11 of the isolates were actually $C$. dubliniensis.

In the present study, it was found that two of 37 samples previously identified as $C$. albicans were actually $C$. dubliniensis, for percentage of $5.4 \%$.

In Brazil, C. dubliniensis was isolated for the first time in two AIDS patients in the state of São Paulo. One patient was a 3-year-old child with oropharyngeal candidiasis ${ }^{34}$ and the other was an adult ${ }^{24}$. ALVES et al. ${ }^{1}$ reported the first three cases of $C$. dubliniensis isolation from AIDS patients in the state of Rio Grande do Sul.

According to MARIANO et al. ${ }^{20}$ in South America the prevalence of $C$. dubliniensis isolates appears to be less than that encountered in North America.

The incidence of $C$. dubliniensis in HIV-positive and AIDS patients observed in Brazil is less than that encountered in Europe and the United States. MILAN et al. ${ }^{25}$ carried out the first multicenter prospective study of the oral incidence of $C$. dubliniensis in Brazilian HIV-positive and AIDS patients. Their study was conducted over a period of two years, at six medical centers around Brazil that provided treatment for HIV-positive patients. Of a total of 155 samples isolated, $2.8 \%$ were identified as $C$. dubliniensis. In a study done in Ireland, it was found that the incidence of $C$. dubliniensis ranged from 18 to $32 \%$ in HIV-infected individuals ${ }^{3,42}$, while studies conducted in the United States have reported rates ranging from 11.1 to $17.5 \%{ }^{14,21}$.

The isolation of C. dubliniensis in HIV-negative patients has also been reported ${ }^{2,7,12,22,32,43}$. Recent studies have shown that this species is more prevalent in HIV-positive individuals, and it is encountered as a commensal organism that can cause various forms of candidiasis ${ }^{12}$. We point out, that in the present study, of the two samples identified as
C. dubliniensis, one was isolated from an HIV-negative patient who only suffered from erythematous candidiasis.

In this study, the genotypic differentiation between C. albicans and $C$. dubliniensis was carried out by means of PCR, which proved to be a useful and practical method yielding an accurate identification, thereby showing that PCR can be an effective tool for elucidating the epidemiology of $C$. dubliniensis, and for establishing its clinical significance.

\section{RESUMO}

\section{Identificação molecular de amostras de Candida dubliniensis isoladas de lesões orais de pacientes HIV positivos e negativos em São Paulo, Brasil}

Candida dubliniensis é uma nova espécie recentemente descrita. Este patógeno oral emergente compartilha muitas características fenotípicas e bioquímicas com $C$. albicans dificultando assim a diferenciação entre elas. As mesmas, porém, mostram-se genotipicamente distintas. Este trabalho tem como objetivo identificar, pela técnica de PCR (Polymerase Chain Reaction), a possível presença de $C$. dubliniensis dentre amostras isoladas de candidose oral eritematosa, provenientes de pacientes HIV positivos e HIV negativos. Em um total de 37 amostras identificadas anteriormente, por método clássico, como $C$. albicans encontramos duas amostras de $C$. dubliniensis $(5,4 \%)$ utilizando a técnica do PCR. Esta técnica mostrouse útil, prática e com identificação taxonômica mais acurada.

\section{ACKNOWLEDGMENTS}

Our thanks go to FAPESP, UNIFAL-MG, USP for financial support, and to Dr. John Norman for his revision of the English manuscript.

\section{REFERENCES}

1. ALVES, S.H.; MILAN, E.P.; BRANCHINI, M.L.M. et al. - First isolation of Candida dubliniensis in Rio Grande do Sul, Brazil. Diagn. Microbiol. infect. Dis., 39: 165 $168,2001$.

2. BRANDT, M.E.; HARRISON, L.H.; PASS, M. et al. - Candida dubliniensis fungemia: the first four cases in North America. Emerg. infect. Dis., 6: 46-49, 2000.

3. COLEMAN, D.C.; SULLIVAN D.J.; BENNETT, D.E. et al. - Candidiasis: the emergence of a novel species Candida dubliniensis. AIDS, 11: 557-567, 1997.

4. COLEMAN, D.C.; SUlLIVAN, D.J.; HARRINGTON, B. et al. - Molecular and phenotypic analysis of Candida dubliniensis: a recently identified species linked with oral candidosis in HIV-infected and AIDS patients. Oral Dis., 3(suppl. 1): 96$101,1997$.

5. COLOMBO, A.L.; PERFECT, J.; DINUBILE, M. et al. - Global distribution and outcomes for Candida species causing invasive candidiasis: results from an international randomized double-blind study of caspofungin versus anphotericin B for the treatment of invasive candidiasis. Europ. J. clin. Microbiol. infect. Dis., 22: 470-474, 2003.

6. FISCHER-HOCH, S.P. \& HUTWAGNER, L. - Opportunistic candidiasis: an epidemic of the 1980s. Clin. infect. Dis., 21: 897-904, 1995.

7. FOTEDAR, R. \& AL HEDAITHY, S.S. - Prevalence of Candida dubliniensis among germ tube-positive yeasts recovered from the respiratory specimens in HIV-negative patients. Mycoses, 47(3-4): 150-155, 2004. 


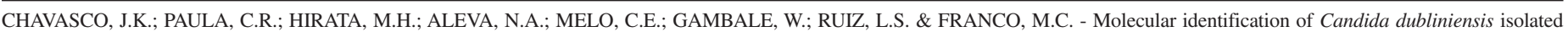
from oral lesions of HIV-positive and HIV-negative patients in São Paulo, Brazil. Rev. Inst. Med. trop. S. Paulo, 48(1): 21-26, 2006.

8. GIAMMANCO, G.M.; PIZZO, G.; PECORELLA, S. et al. - Identification of Candida dubliniensis among oral yeast isolates from an Italian population of human immunodeficiency virus-infected (HIV+) subjects. Oral Microbiol. Immunol., 17: 89-94, 2002.

9. JABRA-RIZK, M.A.; BAQUI, A.A.; KELLEY, J.I. et al. - Identification of Candida dubliniensis in a prospective study of patients in the United States. J. clin. Microbiol., 37: 321-326, 1999.

10. JABRA-RIZK, M.A.; FALKLER Jr., W.A.; MERZ, W.G. et al. - Retrospective identification and characterization of Candida dubliniensis isolates among Candida albicans clinical laboratory isolates from human immunodeficiency virus (HIV)infected and non-HIV-infected individuals. J. clin. Microbiol., 38: 2423-2426, 2000.

11. JOLY, S.; PUJOL, C.; RYSZ, M.; VARGAS, K. \& SOLL, D.R. - Development and characterization of complex DNA fingerprinting probes for the infectious yeast Candida dubliniensis. J. clin. Microbiol., 37: 1035-1044, 1999.

12. KANTARCIOGLU, A.S. \& YÜCEL, A. - The presence of fluconazole-resistant Candida dubliniensis strains among Candida albicans isolated from immunocompromised or otherwise debilitated HIV negative Turkish patients. Rev. iberoamer. Micol., 19: 44-48, 2002.

13. KHAN, Z.U.; AHMAD, S.; MOKADDAS, E. \& CHANDY, R. - Tobacco agar, a new medium for differentiating Candida dubliniensis from Candida albicans. J. clin. Microbiol., 42: 4796-4798, 2004

14. KIRKPATRICK, W.R.; REVANKAR, S.G.; MCATEE, R.K. et al. - Detection of Candida dubliniensis in oropharyngeal samples from human immunodeficiency virus-infected patients in North America by primary CHROMagar Candida screening and susceptibility testing of isolates. J. clin. Microbiol., 36: 3007-3012, 1998.

15. KURTZMAN, C.P. \& FELL, J.W. - The yeasts: a taxonomic study. New York, Elsevier, 1998

16. KURZAI, O.; HEINZ, W.J.; SULLIVAN, D.J. et al. - Rapid PCR test for discriminating between Candida albicans and Candida dubliniensis isolates using primers derived from the pH-regulated PHRI and PHR2 genes of C. albicans. J. clin. Microbiol., 37: 1587-1590, 1999.

17. LEES, E. \& BARTON, R.C. - The use of niger seed agar to screen for Candida dubliniensis in the clinical microbiology laboratory. Diagn. Microbiol. infect. Dis., 46: 13-17, 2003

18. MAGEE, B.B.; D’SOUZA, T.M. \& MAGEE, P.T. - Strain and species identification by restriction fragment length polymorphisms in the ribosomal DNA repeat of Candida species. J. Bact., 169: 1639-1643, 1987.

19. MANNARELLI, B.M. \& KURTZMAN, C.P. - Rapid identification of Candida albicans and other human pathogenic yeasts by using short oligonucleotides in a PCR. J. clin. Microbiol., 36: 1634-1641, 1998.

20. MARIANO, P.L.S.; MILAN, E.P.; MATTA, D.A. \& COLOMBO, A.L. - Candida dubliniensis identification in Brazilian yeast stock collection. Mem. Inst. Oswaldo Cruz, 98: 533-538, 2003.

21. MEILLER, T.F.; JABRA-RIZK, M.A.; BAQUI, A. et al. - Oral Candida dubliniensis as a clinically important species in HIV-seropositive patients in the United States. Oral Surg. oral Med. oral Path. oral Radiol. Endod., 88: 573-580, 1999.

22. MEIS, J.F.G.M.; RUHNKE, M.; De PAUW, B.E. et al. - Candida dubliniensis candidemia in patients with chemotherapy-induced neutropenia and bone marrow transplantation. Emerg. infect. Dis., 5: 150-153, 1999.

23. MEYER, W.; MASZEWSKA, K. \& SORREL, T.C. - PCR fingerprinting: a convenient molecular tool to distinguish between Candida dubliniensis and Candida albicans. Med. Mycol., 39: 185-193, 2001.
24. MILAN, E.P.; COLOMBO, A.L.; LAET SANT’ANA, P.; LEWI, D.S. \& MELO, A.S.A - Primeiro isolamento de Candida dubliniensis no Brasil: In: CONGRESSO BRASILEIRO DE INFECTOLOGIA, 11., São Paulo, 1999. Resumos. p. 32.

25. MILAN, E.P.; LAET SANT'ANA, P.; MELO, A.S.A. et al. - Multicenter prospective surveillance of oral Candida dubliniensis among adult Brazilian human immunodeficiency virus-positive and AIDS patients. Diagn. Microbiol. infect. Dis., 41: 29-35, 2001.

26. MORAN, G.P.; SULLIVAN, D.J.; HENMAN, M.C. et al. - Antifungal drug susceptibilities of oral Candida dubliniensis isolates from human immunodeficiency virus (HIV) infected and non-HIV-infected subjects and generation of stable fluconazole-resistant derivatives in vitro. Antimicrob. Agents Chemother., 41: 617-623, 1997.

27. ODDS, F.C.; VAN NUFFEL, L. \& DAMS, G. - Prevalence of Candida dubliniensis isolates in a yeast stock collection. J. clin. Microbiol., 36: 2869-2873, 1998.

28. PARK, S.; WONG, M.; MARRAS, S.A.E. et al. - Rapid identification of Candida dubliniensis using a species-specific molecular beacon. J. clin. Microbiol., 38: 28292836, 2000.

29. PFALLER, M.A.; HOLLIS, R.J.; SADER, H.S. et al. - Chromosomal restriction fragment analysis by pulsed-field gel electrophoresis. In: INSEBERG, H.D. Clinical Microbiology procedures handbook. Washington, American Society for Microbiology, 1994. p. 200.

30. PFALLER, M.A.; MESSER, S.A.; BOLMSTRÖM, F.C.; ODDS, F.C. \& REX, J.H. Multisite reproducibility of the Etest MIC method for antifungal susceptibility testing of yeast isolates. J. clin. Microbiol., 34: 1691-1693, 1996.

31. PINJON, E.; SULLIVAN, D.; SALKIN, I.; SHANLEY, D. \& COLEMAN, D. - Simple, inexpensive, reliable method for differentiation of Candida dubliniensis from Candida albicans. J. clin. Microbiol., 36: 2093-2095, 1998.

32. POLACHECK, I.; STRAHILEVITZ, J.; SULLIVAN, D. et al. - Recovery of Candida dubliniensis from non-human immunodefficiency virus-infected patients in Israel. J. clin. Microbiol., 38: 170-174, 2000.

33. SALKIN, I.F.; PRUITT, W.R.; PADHYE, A.A. et al. - Distinctive carbohydrate assimilation profiles used to identify the first clinical isolates of Candida dubliniensis recovered in the United States. J. clin. Microbiol., 36: 1467, 1998.

34. SANO, A.; VILELA, M.M.; TAKAHASHI, I. et al. - Isolation of Candida dubliniensis from the oral cavity of an HIV-positive child in Brazil. Nippon Ishinkin Gakkai Zasshi, 41: 177-181, 2000

35. SCHOOFS, A.; ODDS, F.C.; COLEBUNDERS, R.; IEVEN, M. \& GOOSSENS, H. Use of a specialised isolation media for recognition and identification of Candida dubliniensis isolates from HIV-infected patients. Europ. J. clin. Microbiol. Dis., 16: 296-300, 1997.

36. SCHORLING, S.R.; KORTINGA, H.C.; FROSCHB, M. \& MÜHLSCHLEGEL, F.A. The role of Candida dubliniensis in oral candidiasis in human immunodeficiency virus-infected individuals. Crit. Rev. Microbiol., 26: 59-68, 2000.

37. STAIB, P. \& MORSCHHAUSER, J. - Chlamydospore formation on Staib agar as a speciesspecific characteristics of Candida dubliniensis. Mycoses, 42: 521-524, 1999.

38. SMITH, R.A.; HITCHCOCK, C.A.; EVANS, E.G.V.; LACEY, C.J. \& ADAMS, D.J. The identification of Candida albicans strains by restriction fragment length polymorphism analysis of DNA. J. med. vet. Mycol., 27: 431-434, 1989.

39. SULLIVAN, D.J.; WESTERNENG, T.J.; HAYNES, K.A; BENNET, D.E. \& COLEMAN, D.C. - Candida dubliniensis sp. nov.: phenotypic and molecular characterization of a novel species associated with oral candidosis in HIV-infected individuals. Microbiology, 141: 1507-1521, 1995.

40. SULLIVAN, D.J.; HAYNES, K.; BILLE, J. et al. - Widespread geographic distribution of oral Candida dubliniensis strains in human immunodeficiency virus-infected individuals. J. clin. Microbiol., 35: 960-964, 1997. 
CHAVASCO, J.K.; PAULA, C.R.; HIRATA, M.H.; ALEVA, N.A.; MELO, C.E.; GAMBALE, W.; RUIZ, L.S. \& FRANCO, M.C. - Molecular identification of Candida dubliniensis isolated from oral lesions of HIV-positive and HIV-negative patients in São Paulo, Brazil. Rev. Inst. Med. trop. S. Paulo, 48(1): 21-26, 2006.

41. SUlliVAN, D. \& COLEMAN, D. - Candida dubliniensis: characteristics and identification. J. clin. Microbiol., 36: 329-334, 1998.

42. SULLIVAN, D.J.; MORAN, G.; DONNELLY, S. et al. - Candida dubliniensis: an update. Rev. iberoamer. Micol., 16: 72-76, 1999.
43. WILliS, A.M.; COULTER, W.A.; SULLIVAN, D.J. et al. - Isolation of Candida dubliniensis from insulin-using diabetes mellitus patients. J. oral Path. Med., 29: $86-90,2000$

Received: 29 March 2005

Accepted: 25 August 2005 